\title{
The Main "Features" of Admission to Graduate School in Modern Russia
}

\author{
Aleksandr Litvinyuk ${ }^{1},{ }^{*}$ Liliya Babynina ${ }^{1}$. Evgeniya Shubenkova ${ }^{1}$, Elena \\ Karpenko $^{1}$
}

\author{
${ }^{1}$ Plekhanov Russian University of Economics, Moscow, Russia \\ *Email: litvinyuk.aa@rea.ru
}

\begin{abstract}
Postgraduate studies' effectiveness has had a pronounced downward trend in the last decade. The share of graduate students defending their dissertation on time has decreased to $12 \%$. In our opinion, the reason is a decrease in the level of social prestige of both an academic degree and, in general, the idea of building a career trajectory within the academic labour market.

Most master's degree (speciality) graduates consider postgraduate studies as a "backup option", which can be used to survive their temporary difficulties in the labour market. The human resources potential of academic organisations is not improving simultaneously. Until now, the bulk of effective scientific research is carried out mainly by fairly old specialists. And, if specified quantitative indicators are somehow achieved in domestic higher education and science, then the qualitative composition of young specialists coming to universities often wants the best.
\end{abstract}

Keywords: Personnel rejuvenation, Postgraduate studies, Social prestige, Higher school, Science.

\section{INTRODUCTION}

The innovative development of the socio-economic sphere of any state should objectively be based not only on economic and technological components but also on the creative behaviour of young people as the most creative and active part of society. Consistent strengthening of the positions of the Russian Federation in the foreign policy and economic spheres is impossible without involving talented and active representatives of the younger generation of our country in these processes.

It is she who assumes the implementation in the society of such essential functions as:

- reproduction of the main socio-economic achievements and preservation of the stability of the development of science, culture and economy;

- formation of competitive directions for the development of the Russian economy and, most importantly, its high-tech industries.
Global changes in the socio-economic life of our country, the rapid transition to a market mechanism for regulating economic relations in the 90 s of the 20th century led to a negative situation when a sufficiently effective Soviet system of continuous training of scientific personnel was de facto destroyed. Changes in social trends and, first of all, a decrease in the social prestige of work in the academic field, combined with a far from a high level of material rewards, led to a significant outflow of promising young and middle-aged specialists to other sectors of the economy. The consequence of this was a violation of the continuity of generations in Russian science and higher education, which contributed to the collapse of many scientific schools, a decrease in the scientific research effectiveness and the decline of the scientific personnel's reproduction system. The inevitable result was a personnel crisis in the field of activity we are investigating. This has created a real threat of reducing the effectiveness of science and stagnation of Russia's innovation potential.

The younger generation in the modern Russian Federation is a new generation of labour resources. Its 
mentality has been fully formed in a market environment. Based on the data of our previous empirical studies, it can be argued that it is inherently inherent in such features as:

- incomplete immersion in real-life social and economic relations, expressed in the opposition of their personal interests to the interests of the state;

- a pronounced manifestation of pragmatism in building one's career trajectory, which modern employers often perceive as an insufficiently high level of staff loyalty;

- the prevailing motivation to receive a quick material return from the results of their work, etc. [1, pp. 47-49].

All of the above naturally leads to a situation where talented young people often perceive professional development planning within the academic labour market as unacceptable and socially unattractive due to the low starting level of material rewards and the slow growth of a professional career. The current state of affairs objectively forms the purpose of our scientific research a deep scientific study of such aspects of the problem as:

- identification and analysis of the impact on organisational behaviour of essential features of motivational attitudes that promote or hinder the attraction of talented youth to the academic labour market;

- the study of significant environmental factors of influence that favour (complicate) the employment of promising young professionals in the fields of intellectual activity studied by us.

At the same time, we assume that the primary motivational differences contributing to the consolidation of talented young people in intellectual fields of activity are reduced to the different power of the motives of energy-saving and satisfaction on their work behaviour. The significant environmental factors that favour or hinder the employment of young professionals are the result of errors in the formation of a system of motivation for their work at the start of a professional career.

\section{RESEARCH METHODOLOGY}

The methodological basis of the study was the systematic, interdisciplinary, cultural and meta-subject approaches in educational management. In the course of the study, works on the problems of psychology, pedagogy and personnel management with a search depth of 20 years were analysed.

Within the framework of our theory of the motivational complex of labour activity, a digital diagnostic technique was developed and brought to the level of practical application - "A test system for determining the structure of a person's motivational complex" [2]. The methodology makes it possible to determine the structural parameters of the labour motivation and predict the characteristic features of the labour behaviour of the organisation's personnel. It was used as the primary methodological support for the conduct of this study.

\section{RESEARCH RESULTS}

The authors calculated and analysed the features of the motivational profile of young professionals focused on employment in science and higher education and quite successful in this field, according to their managers and the value of the h-index. The respondents were 198 scientific and pedagogical workers of the Plekhanov Russian University of Economics. The sample structure was as follows: $53.03 \%$ of respondents belonged to the university's administrative and managerial staff, and $46.97 \%$ - to the teaching or scientific staff. They formed two groups, the comparative analysis of motivational profiles, chosen as the research's first local task.

The interpretation of the obtained results was based on the main provisions of the "Theory of the motivational complex of labour activity" [3, pp. 213-237].

Below we present the averaged motivational profiles of representatives of each of the groups calculated in automatic mode (Table 1). Averaging the results was carried out by introducing the matrix of the software product mentioned above, the most frequent answers of the group respondents.

Analysing the above averaged motivational profiles, we can draw the following conclusions:

- the organisational behaviour of young specialists from among the teaching staff is much more elastic in relation to changes in the amount of material rewards than that of their peers, whose labour functionality is rigidly formed based on solving administrative tasks $(\mathrm{R}$ $\mathrm{MA}=+2)$;

- representatives of young people who are the object of the academic labour market are strongly influenced by the characteristics of their professional activity of satisfaction motives $\left(\mathrm{R}_{\mathrm{ME}}=+4\right)$. labour operations that cause them positive emotions are the highest priority for this group of respondents;

- young teachers and scientists, unlike their peers, performing administrative functions, more thoroughly adhere to the established University labour regulations $\left(\mathrm{R}_{\mathrm{MS}}=+2\right)$, much less focused on the fulfilment of informal group norms $\left(\mathrm{R}_{\mathrm{MD}}=-2\right)$, they prefer more creative and innovative work $\left(\mathrm{R}_{\mathrm{MP}}=-2\right)$.

Based on the above results, the following diagnostic conclusions can be made during the initial selection of talented students for admission to graduate school and the formation of a personnel reserve in universities and scientific organisations. This is the presence of: 
Table 1. Averaged motivational profiles of the work activity of young specialists of the Plekhanov Russian University of Economics

\begin{tabular}{|c|c|c|c|c|c|}
\hline \multirow[t]{2}{*}{ Groups of respondents } & \multicolumn{5}{|c|}{$\begin{array}{l}\text { The name of the basic motives of labour activity and the strength of } \\
\text { their impact on organisational behaviour in conditional points [3, pp. } \\
\qquad 30-31] \text {. }\end{array}$} \\
\hline & 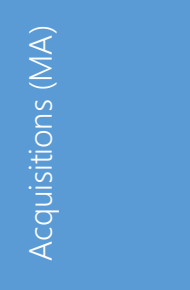 & 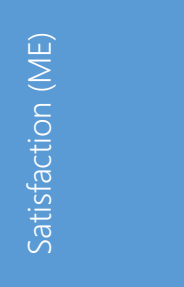 & $\frac{\frac{\pi}{\omega}}{n} \sum^{n}$ & 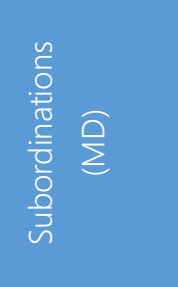 & 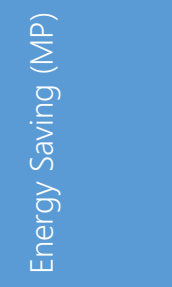 \\
\hline $\begin{array}{l}\text { A. Teaching staff and researchers under } \\
\text { the age of } 35\end{array}$ & 3,0 & 6,0 & 4,0 & 0,0 & $-2,0$ \\
\hline $\begin{array}{l}\text { B. Administrative and managerial staff } \\
\text { under the age of } 35\end{array}$ & 1,0 & 2,0 & 2,0 & 2,0 & 0,0 \\
\hline $\begin{array}{l}\text { The range of variation }(R=\text { The average } \\
\text { indicators of group } A \text { minus the average } \\
\text { indicators of group } B) \text { : }\end{array}$ & $\mathrm{RMA}=(+2,0)$ & $R M E=(+4,0)$ & $\mathrm{RMS}=(+2,0)$ & RMD $=(-2,0)$ & $\operatorname{RMP}=(-2,0)$ \\
\hline
\end{tabular}

Source: authors' data.

- a high level of elasticity of labour behaviour in relation to the motives of MA, ME and MS;

- low elasticity level for MD and MP motifs.

In the development of the study of this problem, we attempted to study the features of the structure of the motivational profile of bachelors and masters, potentially capable of becoming effective youth personnel for science and higher education (the second local task of the study). To this end, we conducted a comparative analysis of the motivational profiles of two groups of respondents (Table 2):

- bachelors and masters who consciously want to continue their postgraduate studies in the future and link their professional activities with science and higher education (group C);

- bachelors and masters who consciously do not want to continue their education in graduate school (group D).

Comparing the above averaged motivational profiles (Table 2) with similar parameters of group A (Table 1), it can be concluded that the structure of the motivational complex of the teaching staff and researchers under the age of 35 correlates much more with the indicators of group D, and not group C. (The standard Spearman coefficient in the first case was 1.000 and in the second 0.675 .

Consequently, university graduates who are not motivated to find employment in the academic labour market have a much more similar motivational profile in relation to successful young scientists and university teachers than those who intend to continue their studies in graduate school. But it is the latter who will occupy key positions in the academic field in 7-8 years.

Analysing the ways to solve the problem of attracting young specialists to science and higher education with a motivational profile more suitable for these areas of work, we can formulate the following general recommendations:

- it is necessary to work at the state level to increase the social prestige of employment within the academic labour market, especially since such a positive experience in the Russian Federation, concerning military service, has already been successfully implemented through the media;

- it is necessary to develop and implement a system for selecting applicants for admission to a budget postgraduate school, considering the target motivational features we have identified. Focusing on such criteria, it is possible to purposefully form a reserve for the reproduction of human resources in the field of science and higher education;

- a completely different state policy of material stimulation of labour in the subjects of the academic market is necessary. It should assume a decent level of material remuneration and a high focus on the current, not on the specialist's past professional achievements. 
Table 2. The average motivational profiles of the work activity of the surveyed bachelors and undergraduates

\begin{tabular}{|l|c|c|}
\hline \multirow{2}{*}{\begin{tabular}{l} 
Motives of labour \\
\multirow{2}{*}{ activity }
\end{tabular}} & \multicolumn{2}{|c|}{$\begin{array}{c}\text { Groups of respondents and the power of influence on their organisational behaviour of } \\
\text { basic motives in conditional points }\end{array}$} \\
\cline { 2 - 3 } & $\mathrm{C}$ & +3 \\
\hline $\mathrm{MA}$ & +5 & +5 \\
\hline $\mathrm{MS}$ & +3 & +4 \\
\hline $\mathrm{MD}$ & +3 & +1 \\
\hline $\mathrm{MP}$ & +1 & -5 \\
\hline
\end{tabular}

To retain talented young professionals already working in organisations in the field of science and higher education, it would be advisable to provide for the possibility of receiving additional material rewards within the framework of postdoctoral training. Such a financial incentive tool involves the long-term work of a young specialist under the patronage of an experienced scientist. This can be both jointly carried out scientific research and teaching activities, which, according to most foreign authors [4 and 5], is, in some way, a mentoring option.

Firstly, it will increase the level of continuity in science and higher education.

Secondly, it will provide an objective opportunity to improve the quality of scientific grants and projects implemented by young specialists.

Thirdly, the professional activity of a young specialist in postgraduate studies will allow him to decide on terms of building his career trajectory finally.

\section{RESULTS \& DISCUSSION}

In modern HR management, many classifications of organisational behaviour motives and methods and algorithms developed on their basis are used to determine the structure of the motivational complex and to predict the behaviour of personnel in the workplace.

Among the classical developments, it makes sense to include the work of such scientists in the field of management and psychology as K. Alderfer [6], J.S. Adams [7] and V. Vroom [8].

Among the modern theories of motivation and stimulation of labour in HR management, one can note the works of J. Hunter [9] and Sh. Richie [10].

Traditionally, most foreign scientists identify five groups of leading motives that young specialists are guided by when entering graduate school: more effective career development; interest in the scientific problem being studied; personal motives; life experience and advice from representatives of reference groups [11].

In September 2020, the authors conducted an anonymous express survey of 127 Plekhanov Russian University of Economics students who decided to enter graduate school after defending their master's thesis. The distribution of responses according to the frequency of their statements about the real motives of such a decision was as follows:

- it is difficult to determine your career trajectory quickly, and postgraduate studies make it possible to expand the time frame for finding an acceptable employment option (40.6\%);

- postgraduate studies can be combined with work, and the presence of an academic degree accelerates a professional career $(27.5 \%)$;

- it is interesting to engage in scientific activity and teach at a university $(15.0 \%)$;

- I find it difficult to answer clearly (9.7\%);

- it is possible to postpone conscription or avoid it altogether $(7.2 \%)$.

Thus, we see that most young professionals consider the third level of education not as a potential employment opportunity in the academic labour market but as a kind of "temporary shelter" until a more exciting employment option appears for them. A very similar situation is observed in some foreign countries [12], where postgraduate studies are often necessary for successful employment not in academics but a completely different field of work.

The problem we are investigating is not purely domestic. In countries where much more resources are invested in developing this field of activity than in the Russian Federation, they face similar behavioural tendencies of young professionals [12]. Moreover, the main reasons for the reluctance to develop a career in our study field are also based on the material component. 


\section{CONCLUSIONS}

The conclusions made by the authors, in a generalised form, are following:

- a successful professional career within the academic labour market is ensured by the presence of young professionals with a high positive sensitivity to the motives of acquisition, satisfaction and security, and high negative sensitivity to the motives of subordination and energy conservation;

- most graduates of Russian universities who wish to build their career trajectory in the field of science and higher education, from the point of view of the structure of their motivational complex, are not quite suitable for this kind of work;

- those graduates who consciously do not want to find a job in the academic labour market are more suitable for work in the field of science and higher education;

- the main factors of the external environment that prevent the influx of talented and creative youth into science and higher education are the inefficient motivation of work in this field of activity; a long-time lag of professional development; lack of stable employment in the academic labour market; low social prestige of the career of a scientist and a university teacher in our country.

In our opinion, it is necessary not so much to pay increased attention to the creation of additional jobs in the academic labour market to consider the motivation and creative potential of the young professionals involved.

\section{AUTHORS CONTRIBUTION}

Litvinyuk A.A. - scientific article editorial, conducting surveys and processing their results.

Babynina L.S. - analysis of foreign research on the subject of the article.

Shubenkova E.V. - participation in the survey of respondents.

Karpenko E.Z. - analysis of Russian research on the subject of the article

\section{REFERENCES}

[1] V.N. Bobkov, A.A. Litvinyuk, Russian youth in the labour market: economic activity and employment problems [Rossijskaya molodyozh' na rynke truda: ekonomicheskaya aktivnost' i problemy trudoustrojstva], Moscow: Rusains LLC, 2016, 228 p. DOI: https://doi.org/10.15216/978-5-4365-1372$\underline{0}$
[2] A.A. Litvinyuk, M.E. Smirnova, R.A. Shirvanov, On the methodology of forecasting the organisational behaviour of the organisation's personnel $[\mathrm{O}$ metodike prognozirovaniya organizacionnogo povedeniya personala organizacii] // Innovations in Management [Innovacii v menedzhmente] 2(6) (2018) 42-57.

[3] A.A. Litvinyuk, Yu.N. Kleshchevsky, E.V. Kuzub, S.A. Ledneva, The motivation of youth employment in science, high technology and higher education [Motivaciya trudoustrojstva molodyozhi v sfere nauki, vysokih tekhnologij i vysshego obrazovaniya], Moscow: Creative Economy [Moskva: Kreativnaya ekonomika], 2019, 246 p DOI: https://doi.org/10.18334/9785912922916

[4] J.M. Miller, M.P. Feldman, Isolated in the lab: Examining dissatisfaction with postdoctoral appointments, The journal of higher education 56(5) (2015) 697-724. DOI: https://doi.org/10.1353/jhe.2015.0029

[5] Inge van der Weijden, Christine Teelken, Moniek de Boer \& Mariske Drost, Career satisfaction of postdoctoral researchers in relation to their expectations for the future, Higher Education 72 (2016) 25-40. DOI: https://doi.org/10.1108/ER-122016-0241

[6] C.P. Alderfer, Existence, Relatedness, and Growth; Human Needs in Organisational Settings, New York: Free Press, 1972, 198 p.

[7] J.S. Adams, Freedman, S. Equity theory revisited: Comments and annotated bibliography, In Advances in experimental social psychology, Academic Press 9 (1976) 43-90.

[8] V. Vroom, Work, and motivation, NYC: Wiley, 1964, $331 \mathrm{p}$.

[9] J.E. Hunter, F.L. Schmidt, Methods of metaanalysis: Correcting error and bias in research findings, Newbury Park, CA: Sage, 2004, 245 p. DOI: https://doi.org/10.2307/2289738

[10] Sh. Richie, Motivation management [Upravlenie motivaciej], Moscow: UNITY-DANA, 2004, 399 p.

[11] H. Churchill, T. Sanders, Getting your PhD: A practical insider's guide. Thousand Oaks, CA: Sage Publications, 2007, 197 p.

[12] C.S. Hayter, M.A. Parker, Factors that influence the transition of university postdocs to non-academic scientific careers: an exploratory study // Research Policy 48(3) (2019) 556-570. DOI: https://doi.org/10.1016/j.respol.2018.09.009 